\title{
Technological Feasibility of Hovenia dulcis thunb. Species for the Production of Edge Glued Panels
}

\author{
Raquel Marchesan ${ }^{1}$, Pedro Lício Loiola², Tânia Vieira de Mello ${ }^{3}$, \\ Márcio Pereira da Rocha ${ }^{2}$, José Reinaldo Moreira da Silva ${ }^{4}$ \\ ${ }^{1}$ Programa de Pós-graduação em Engenharia Florestal, Departamento de Engenharia Florestal, Universidade Federal do \\ Paraná - UFPR, Curitiba/PR, Brasil \\ ${ }^{2}$ Departamento de Engenharia Florestal, Universidade Federal do Paraná - UFPR, Curitiba/PR, Brasil \\ ${ }^{3}$ Departamento de Engenharia Florestal, Universidade Estadual do Centro Oeste - UNICENTRO, Irati/PR, Brasil \\ ${ }^{4}$ Departamento de Engenharia Florestal, Universidade Federal de Lavras - UFLA, Lavras/MG, Brasil
}

\begin{abstract}
This study aims to evaluate the use of Hovenia dulcis wood to produce Edge Glued Panels - EGP. To this end, joints with dimensions of $5.0 \times 31.0 \times 2.5 \mathrm{~cm}$ (Width $\times$ Length $\times$ Thickness) were put together using polyvinyl acetate (PVAc) and emulsion polymer isocyanate (EPI) adhesives at a spread rate of $200 \mathrm{~g} . \mathrm{m}^{-2}$ and the chemical characterization of the wood was performed. The strength of glued joints was evaluated through shear tests based on the procedures described by established standards. The results showed that the EPI adhesive achieved the best results in edge gluing to produce EGP. The use of PVAc adhesive did not show satisfactory results for edge gluing under these conditions. Hovenia dulcis wood is indicated for producing higher value-added wood products - (VAWP) for external use purposes.
\end{abstract}

Keywords: uva-do-japao, value added wood products, gluing. 


\section{INTRODUCTION}

The forestry sector makes an important contribution to the Brazilian economy, both in production for domestic consumption and for export purposes, with an important role in job creation and revenue generation (IBÁ, 2014).

Due to the growing demand for forest products and the constant concern with pressure on native forests, there is a need to look for fast-growing species with the potential to supply lumber/timber for forest-based industries, such as wood used for manufacturing paper and cellulose, energy, sawmills, and the furniture industry, among others.

Among the non-conventional species that can supply the forestry market, we can highlight Hovenia dulcis Thunberg. This species belongs to the Rhamnaceae family, originated in Japan, China and Korea, and popularly known in Brazil as "uva-do-japão" (Rigatto et al., 2001).

According to Vivian et al. (2011) and Motta et al. (2014), Hovenia dulcis wood has a basic density ranging from 0.51 to $0.65 \mathrm{~g} . \mathrm{cm}^{-3}$ and anisotropic factor of 1.50 , being classified as medium basic density wood with good stability. This makes it an alternative for use in the timber industry to manufacture flooring and furniture, which are high value-added products.

The species has easy natural regeneration and pioneering characteristics. Therefore, the species is found in several regions such as in the Semi-deciduous Seasonal Forest and the Mixed Ombrophylous Montana Forest (Forest with Araucaria). There are currently small plantings of the species established by seed or seedlings in the states of Rio Grande do Sul, Santa Catarina and Paraná (Carvalho, 1994; Sellers, 1994).

Given the different uses of wood and the production processes that generate environmental liabilities, and in order to improve efficiency in the use of wood and its residues, the best alternative is to produce new materials, which are called Value-Added Wood Products (VAWP); a category which includes edge glued panels (EGP) (Bila, 2014). The wood sector currently presents great product diversification, with a wide range of options for adhesives and other materials in order to increase the effectiveness and quality of the products obtained.

EGP, which stands for Edge Glued Panels, refers to a set of battens which are glued laterally using an adhesive, which may or may not be top-joined, and have or not sheet coverings and backings (Iwakiri, 2005; IBÁ, 2014).

National production mostly uses pine wood, however, edge glued panels made from hardwoods are also found (IBÁ, 2014). Edge glued panels are used in construction and furniture manufacturing due to their decorative traits and structural characteristics (Mattos et al., 2008).

Iwakiri (2005) reports that the advantage of making panels with the use of small battens is the economic return, considering that small pieces of sawmill waste and trees with smaller diameters can be used. This is already a developmental trend stemming from modern sawing techniques which add value to byproducts generated from mechanical wood processing.

In order to obtain a sturdy bond with maximum efficiency, it is necessary for the adhesive to have the ability to transfer tension from one substrate to another without losing resistance or cohesion (Haubrich et al., 2007).

Moreover, understanding the chemical properties of wood is of paramount importance, as they may benefit or impair the bonding of EGP panels, depending on the type of extractive that is found in their composition (Klock et al., 2005).

In this context, the objective of this study is to determine the viability of Hovenia dulcis wood for producing edge glued panels using two types of adhesives (EPI and PVAc) through mechanical shear testing, in addition to defining the chemical properties of both the wood and adhesives.

\section{MATERIAL AND METHODS}

\subsection{Material collection and manufacture of the wood joints}

In order to perform this study, 16 logs were obtained from five Hovenia dulcis trees with a mean diameter of $23 \mathrm{~cm}$, commercial height of $8.25 \mathrm{~m}$ and an average age of 18 years. The logs were sawn on a horizontal band saw to obtain $25 \mathrm{~mm}$ thick, $1800 \mathrm{~mm}$ long planks with widths according to the diameter of the logs.

The boards were dried in a conventional drying chamber to achieve a moisture content of $12 \%$. They were 
subsequently re-sawn and flattened to obtain pieces with final dimensions of $5.0 \times 2.5 \times 31.0 \mathrm{~cm}(\mathrm{H} \times \mathrm{T} \times \mathrm{W})$ for manufacturing glued joints.

Bonding was carried out in a high frequency press for 90 seconds, and two types of adhesives were evaluated: EPI (isocyanate polymer emulsion base) and PVAc (polyvinyl acetate base), with a spread rate/weight of 200 g. $\mathrm{m}^{2}$, and homogeneous distribution throughout the batten. After conditioning in a controlled environment at $20 \pm 1^{\circ} \mathrm{C}$ and $65 \pm 3 \%$ relative humidity, test specimens were prepared for the shear resistance tests along the glue line, according to the standard recommendations of the American Society for Testing and Materials ASTM D-5572 (ASTM, 1999).

\subsection{Edge glue line resistance}

Wet and dry treatments were performed to determine shear resistance along the glued edge according to the EN 13354 (EN, 2009) recommendations for both evaluated adhesives, with 30 replications being used for each treatment, totaling 120 specimens tested.

\subsection{Physical and chemical characterization of the wood}

The basic density and chemical properties of the wood were determined using 5 - $\mathrm{cm}$ thick cross-section discs from the apical (top), average (DBH - diameter at breast height) and basal portions of the felled trees. These were sawn into wedges equivalent to $1 / 4$ of the total of each disc.

Samples without any failures/defects were selected to determine the basic density, totaling 43 specimens, and the experimental procedures were performed according to the recommendations of the ASTM D-2395 (ASTM, 1999).

For the chemical characterization, the discs were transformed into woodchips, which were then reduced into sawdust by a Wiley-type knife mill. Sawdust was subsequently classified using manual sieves; the fractions that passed through the 40 mesh sieve and were retained in the 60 mesh sieve were used to determine the chemical components, according to the TAPPI T 264 om-07 (TAPPI, 1997a) standard.

After classification, the percentage of absolutely dry material was determined in order to make the proper corrections during analysis. Each analysis was conducted in triplicate, and a new analysis was performed when the values diverged by more than $2 \%$. The chemical analyses were: $\mathrm{pH}$ and Electrical Conductivity of Hot Water Extracts - TAPPI T 252 om-12 (TAPPI, 2002a); Solvent Extractives of Wood and Pulp - TAPPI T 204 cm-07 (TAPPI, 1997b); Acid-Insoluble lignin in wood and pulp - TAPPI T 222 om-15 (TAPPI, 2002b); Ash in wood, pulp, paper and paperboard: combustion at $525^{\circ} \mathrm{C}$ - TAPPI T 211 om-12 (TAPPI, 2002c); holocellulose content - determined by difference, including ash content.

\subsection{Adhesive properties}

The $\mathrm{pH}$ of the PVAc and EPI adhesives was measured directly by the calibrated $\mathrm{pH}$ meter, which gives the results based on the usual 0 to $14 \mathrm{pH}$ range, with the adhesives at a temperature of $25^{\circ} \mathrm{C}$ and five replications for each adhesive (EN, 2001a).

To obtain viscosity, the adhesives were stabilized at a temperature of $25^{\circ} \mathrm{C}$. Next, the readings were made using rods 3 and 4 of the viscometer apparatus at speeds of 2, 3, 10 and $20 \mathrm{rpm}$. The average viscosity of the adhesives was then calculated from the results obtained (EN, 2001b).

In order to determine adhesive solid content, $1 \mathrm{~g}$ of adhesive was weighed using five samples per adhesive, which were then placed in an oven for a four-hour period at $105^{\circ} \mathrm{C}$. The results were obtained by mass difference (EN, 2005).

\subsection{Analyzing and evaluating the results}

A completely randomized design with a factorial arrangement was used to compare the results for the glue line resistance in which the following factors were analyzed: adhesive (two levels), pre-treatment (two levels) and the interaction between these factors. First, normality and data distribution (Lilliefors test) tests and homogeneity of variances test (Bartlett and Cochran test) were performed. The Tukey test at $5 \%$ probability was used for significant factors and interaction was detected by the $\mathrm{F}$ test. The mean test is necessary to group the levels of each factor, thereby evidencing the equality or not of the hypothesis. 


\section{RESULTS AND DISCUSSION}

\subsection{Physical and chemical wood properties}

The basic specific mass of Hovenia dulcis wood was $0.58 \mathrm{~g} \mathrm{~cm}^{-3}$. According to the classification suggested by Carvalho (1996), this species can be classified as moderately heavy wood, a classification similar to that suggested by the Brazilian Institute of Environment and Renewable Natural Resources (IBAMA, 2014).

In analyzing the Hovenia dulcis wood, Rigatto et al. (2001) obtained a basic density value of 0.55 g.cm- ${ }^{3}$. Motta et al. (2014) found values between 0.52 and 0.65 g. $\mathrm{cm}^{-3}$ analyzing wood from Espírito Santo of indeterminate age. Bednarczuk (2015) found values ranging from 0.50 and $0.57 \mathrm{~g} \mathrm{~cm}^{-3}$ for sapwood and heartwood at 14 years, respectively. This shows that the values obtained for the basic density of the wood in the present study corroborate those described in the literature (Table 1).

The basic density of the wood is of fundamental importance for the choice of the adhesive, since according to Kollmann \& Côte (1968) it has an inverse relationship with porosity and adhesive penetration. Sellers (1994) countered that, depending on the adhesive and the specific mass of the material to be bonded, the penetration in the wood can vary from three to five cells, filling the cellular cavities and covering the internal walls.

In evaluating bonded joints of Eucalyptus wood, Plaster et al. (2012) found that wood with greater basic density has greater difficulty in adhesion. The authors also reported that high density wood has less adhesive penetration, in addition to greater loss by the edges of the piece to be glued, causing a less effective glue line.

In relation to the $\mathrm{pH}$ of the wood (Table 1), it can be observed that the values obtained for the 2 and 24 hour intervals (6.53 and 6.95 respectively) are close to and corroborate with the hydrogenation potential for hardwoods, as described by Iwakiri (2005). On the other hand, the total extractives content found in Hovenia dulcis wood (5.11\%) was lower than that described by Rigatto et al. (2001) and Miranda et al. (2013), being 7.0 and $14.5 \%$, respectively.

Determining the extractives in wood whose purpose is adhesion is of fundamental importance, as these inorganic components present in the cellular wall can help or hinder the gluing process, having a direct influence on $\mathrm{pH}$ (Sellers, 1994; Lima et al., 2007). The proportion and type of extract present may cause interference in the polymerization reactions of the adhesive, or a reaction between the adhesive and the extractive agent. In general, wood with high levels of extractives present difficulties in bonding (Jankowsky, 1988).

Regarding the extractive content of Hovenia dulcis wood, the value obtained of $5.11 \%$ is considered low when compared to species like Eucalyptus grandis and Tectona grandis. In evaluating the influence of the anatomical characteristics and the total extractive content in Eucalyptus grandis wood on the quality of the bonding, Albino et al. (2012) showed that the extractive content in the region of the pith and on top of the log were $6.10 \%$ and $7.98 \%$, respectively. Loiola (2015) analyzed the drying of teak wood (Tectona grandis L. f) and found total extractive values of $11.13 \%$.

Through these results, we can affirm that $H$. dulcis wood presents better acceptance for surface finishing products such as varnishes, sealants and paints when compared to the species E. grandis and T. grandis, since the excessive quantity of extractives can negatively influence this factor. Thus, when it comes to finishing wood flooring surfaces, we can consider a low extractive content in the wood a positive characteristic.

Table 1. Physical and chemical properties of Hovenia dulcis wood.

\begin{tabular}{|c|c|c|c|c|c|c|}
\hline \multirow{2}{*}{$\begin{array}{c}\text { Hovenia } \\
\text { dulcis }\end{array}$} & \multirow{2}{*}{$\begin{array}{l}\mathrm{SM}_{\text {basic }} \\
\left(\mathrm{g} \mathrm{cm}^{-3}\right)\end{array}$} & \multicolumn{2}{|c|}{ pH } & \multirow{2}{*}{$\begin{array}{c}\text { Total } \\
\text { extractives }\end{array}$} & \multirow{2}{*}{ Lignin } & \multirow{2}{*}{ Holocellulose } \\
\hline & & $2 \mathrm{~h}$ & $24 \mathrm{~h}$ & & & \\
\hline Mean & 0.58 & 6.53 & 6.95 & 5.11 & 26.63 & 67.35 \\
\hline $\mathrm{SD}$ & 0.05 & 0.35 & 0.29 & 0.68 & 1.98 & - \\
\hline CV (\%) & 8.70 & 5.37 & 4.24 & 13.29 & 7.45 & - \\
\hline
\end{tabular}

$\mathrm{SM}_{\text {basic }}$ : basic density; SD: Standard deviation; $\mathrm{CV}(\%)$ :coefficient of variation (\%). 


\subsection{Adhesive properties}

Table 2 shows the solid content, viscosity and $\mathrm{pH}$ values for EPI and PVAc adhesives.

We observed (Table 2) that the solid content (\%) was higher for the emulsion polymer isocyanate (EPI) based adhesive with an average value of $59.55 \%$, while the polyvinyl acetate-based adhesive (PVAc) had a solid content of $45.20 \%$. According to Iwakiri (2005), solid content in adhesives leads to more components that form adhesive bonds to the substrate there by benefiting the bond. This property is of utmost importance in wood bonding because the amount of adhesive that actually remains to form the glue line is determined by it. Marra (1992) states that the solids acquire different properties and assume a new role after adhesive solidification. Cohesion occurs during bonding, causing the solid content to become a bonding mechanism between the two surfaces, thus acquiring strength and durability.

Bianche (2014), as well as Marcati \& Della Lucia (1996) found similar values for the solid content of the PVAc adhesive to those observed for H. dulcis - 45\% and $48.56 \%$, respectively.

Almeida (2013) evaluated the potential of tropical wood waste to produce edge glued panels and obtained $57.82 \%$ solid content for EPI, which is also similar to that found in this study.

A high solid content contributes to the quality of the glue line due to the greater amount of solid material, improving adhesion between the wood and the adhesive (Bianche, 2014).

Regarding the adhesives' viscosity, EPI and PVAc had viscosity values of $11,134.10$ and $3,039.10 \mathrm{cP}$, respectively. Bianche (2014) obtained 9,430 cP for PVAc viscosity in evaluating the wood-adhesive interface and the strength of bonded joints with different adhesives. The viscosity value found in this study was significantly lower than the value obtained by that author. Almeida (2013) found average viscosity values of 5,700 and $10,080 \mathrm{cP}$ for PVAc and EPI adhesives, respectively. The author states that variations in viscosity are very common due to naturally

Table 2. EPI and PVAc adhesive properties.

\begin{tabular}{crr} 
Adhesive & \multicolumn{2}{c}{ Adhesive } \\
\cline { 2 - 3 } properties & EPI & PVAc \\
\hline Solid content (\%) & 59.55 & 45.20 \\
Viscosity (cP) & 11134.40 & 3039.10 \\
$\mathrm{pH}$ & 6.60 & 3.01 \\
\hline
\end{tabular}

occurring changes in the adhesives over time and due to exposure to air during the research development.

Low viscosity adhesives result in better scattering on the surface of the wood due to high fluidity, contributing to greater adhesive penetration and absorption by the cellular structure. However, in some cases this feature may result in a "hungry" glue line, leading to an insufficient amount of adhesive along the glue line.

In analyzing the $\mathrm{pH}$ obtained in both adhesives used, it was observed that the values found are within the range of 2.5 to 11 presented by Iwakiri (2005), as a limit so that the adhesive does not cause degradation of the wood fibers. According to Marra (1992), pH control during adhesive production is one of the most important functions of quality control, since it defines the speed and degree of reactions and the configurations of the molecules. It can also indicate the viability of the adhesives.

\subsection{Edge glue line resistance}

Table 3 shows the mean maximum tension values (MPa) and the fifth lower percentile of the resistance (MPa) of the edge gluing to the shear in Hovenia dulcis wood.

It is worth noting that the values met the EN 13353 (EN, 2008) requirements, which also require that the minimum value of the lower $5^{\text {th }}$ percentile of the panels is greater than or equal to $2.5 \mathrm{MPa}$. Regarding the EPI adhesive, the tests performed in wet and dry conditions had acceptable values for the $5^{\text {th }}$ percentile, with the highest value corresponding to the dry test (9.08 MPa). The edge gluing tests with the PVAc adhesive did not meet the EN 13353 (EN, 2008) standard, since they presented values of 0.70 MPA and 1.40 MPa for wet and dry treatments, respectively, which are lower than what is required by the standard $(2.50 \mathrm{MPa})$.

No treatment met the requirements of EN 13353 (EN, 2008) for wood failure, which should be greater than $40 \%$. In studying six species of the genus Pinus, Prata (2010) also found no wood failure values that satisfied this norm. The author also reported wood failure with specific mass, proving that there is a strong relationship between these variables; meaning that an increase of the apparent specific mass will lead to a decrease in the percentage of wood failure.

Bila (2014) adds that when the wood failure percentage ranges between $0 \%-25 \%$, it indicates low adhesive strength and/or deficiency in the bonding process, 
Table 3. Shear resistance of Hovenia dulcis wood along the gluing edge.

\begin{tabular}{|c|c|c|c|c|c|c|}
\hline \multirow[t]{2}{*}{ Pre-treatment } & \multicolumn{2}{|c|}{ Max. tension (MPa) } & \multicolumn{2}{|c|}{ Wood failure (\%) } & \multicolumn{2}{|c|}{$\begin{array}{c}5^{\text {th }} \text { Percentile } \\
(\mathrm{MPa})\end{array}$} \\
\hline & EPI & PVAc & EPI & PVAc & EPI & PVAc \\
\hline Dry & $\begin{array}{c}12.60 \mathrm{aA} \\
(1.63 ; 12.93)\end{array}$ & $\begin{array}{c}6.33 \mathrm{aB} \\
(2.90 ; 45.88)\end{array}$ & 16.04 & 0.5 & $9.08^{*}$ & 1,40 \\
\hline Wet & $\begin{array}{c}4.43 \mathrm{bA} \\
(1.05 ; 23.60)\end{array}$ & $\begin{array}{c}1.90 \mathrm{bB} \\
(0.85 ; 44.87)\end{array}$ & 6.5 & 0.5 & $3.09^{*}$ & 0,70 \\
\hline $\mathrm{F}$ & & & & & & \\
\hline
\end{tabular}

Averages followed by the same uppercase letter in the line, or lowercase letters in the column do not differ by Tukey test ( $\mathrm{p}>0.05$ ). Values in brackets correspond to standard deviation and coefficient of variation respectively. ${ }^{* *}$ Significance at $1 \%$ probability of error; ${ }^{\star}$ Values that met the minimum requirement according to standard EN 13353 (EN, 2008). Values in parentheses correspond to standard deviation and coefficient of variation (\%), respectively.

such as a smooth surface, low applied weight/adhesive spread rate, or high surface moisture, among others. A percentage between $50 \%$ - 70\% indicates a more suitable bonding process and adhesive properties, while $75 \%$ to $100 \%$ represents stronger adhesive properties.

It is also noted that a statistical difference was obtained for ANOVA at $1 \%$ probability for interaction with the edge gluing resistance to shearing, thus allowing us to affirm that there were differences between the adhesives used in pre-treatment for use in dry conditions and after pre-treatment for use in wet conditions.

Additionally, according to Table 3, we can emphasize that the dry treatment of the EPI adhesive had the best shear resistance result $(12.60 \mathrm{MPa})$, while the wet test of the PVAc adhesive had the lowest result for the same analysis (1.90 MPa).

The EN 204 (2001) guideline determines that maximum tension be greater than or equal to $2.5 \mathrm{MPa}$ for the wet treatment of edge gluing, while EN 13353 (EN, 2008) standard determines a value greater than or equal to $10 \mathrm{MPa}$ for the dry treatment. Thus, we observe that only the EPI adhesive met the requirements determined by these norms.

Iwakiri et al. (2013) found higher values than the present study's values of 9.04 MPa for shear resistance using Eucalyptus benthamii and PVAc adhesive. Plaster et al. (2012) used eucalyptus and PVAc adhesive, and found an unfavorable performance for shear resistance along the glue line.

\section{CONCLUSIONS}

Hovenia dulcis wood is recommended for the production of higher value-added wood products intended for external uses. It is possible to use EPI adhesive for the edge gluing of Hovenia dulcis panels, considering that it has good shear resistance in both wet and dry environments. PVAc adhesive did not obtain the results required by the EN 13353 (EN, 2008) standard for wet and dry conditions.

\section{SUBMISSION STATUS}

Received: 4 feb., 2016

Accepted: 2 july, 2017

\section{CORRESPONDENCE TO}

\section{Raquel Marchesan}

Departamento de Engenharia Florestal, Universidade Federal do Paraná - UFPR, Av.

Prefeito Lothário Meissner, 632, CEP 80210-170, Curitiba, PR, Brasil

e-mail: raquelmarchesan@yahoo.com.br

\section{REFERENCES}

Albino VCS, Mori FA, Mendes LM. Influência das características anatômicas e do teor de extrativos totais da madeira de Eucalyptus grandis w. Hill ex Maiden na qualidade da colagem. Ciência Florestal 2012; 22(4): 803-811. http:// dx.doi.org/10.5902/198050987561.

Almeida VC. Avaliação do potencial de uso de resíduos de madeira tropical para produção de painel colado lateralmente - EGP [tese]. Curitiba: Universidade Federal do Paraná; 2013.

American Society for Testing Materials - ASTM. ASTM 5572-95: standard specification for adhesives used for finger joints in nonstructural lumber products. West Conshohocken: ASTM; 1999. 17 p.

Bednarczuk E. Produção de lâminas e painel compensado multilaminado com madeira de Hovenia dulcis Thunberg (uva-do-japão) [dissertação]. Irati: Universidade Estadual do Centro-Oeste; 2015. 
Bianche J. J. Interface madeira-adesivo e resistência de juntas coladas com diferentes adesivos e gramatura [tese]. Viçosa: Universidade Federal de Viçosa; 2014.

Bila NF. Avaliação da qualidade de juntas coladas de seis espécies de madeiras tropicais da Amazônia [dissertação]. Curitiba: Universidade Federal do Paraná; 2014.

Carvalho A. Denominações convencionais para propriedades da madeira. In: Carvalho A. Tecnologia das indústrias da madeira III - Na2. Lisboa: Direcção Geral das Florestas; 1996. 5 p. vol. I.

Carvalho PER. Ecologia, silvicultura e usos da uva-do-japão (Hovenia dulcis Thunberg). Colombo: EMBRAPA-CNPF; 1994. 24 p. (Circular Técnica; no. 23).

European Standard - EN. EN 1245: adhesives: determination of ph: test method. Bruxelas: EN; 2001a.

European Standard - EN. EN 12092: adhesives: determination of viscosity: test method. Bruxelas: EN; 2001b.

European Standard - EN. EN 827: Adhesives - Determination of convencional solids content and constant mass solids contentTest Method . Bruxelas: EN; 2005.

European Standard-EN. EN 13353: solid wood panels (SWP): requirements. Bruxelas: EN; 2008.

European Standard - EN. EN 13354: solid wood panels (SWP): bonding quality. Bruxelas: EN; 2009.

Haubrich JL, Gonçalves C, Tonet A. Adesivos vinílicos apresentam soluções para madeira. Revista da Madeira 2007; 103: 66-70.

Indústria Brasileira de Árvores - IBÁ. Anuário estatístico da IBÁ 2014: ano base 2013. Brasília: IBÁ; 2014. 100 p.

Instituto Brasileiro do Meio Ambiente e dos Recursos Naturais Renováveis - IBAMA. Banco de dados de madeiras brasileiras. Brasília: IBAMA; 2014. [cited 2014 Nov 13]. Available from: http://www.ibama.gov.br

Iwakiri S, Trianoski R, Cunha AB, Prata JG, Hara M, Bila NF et al. Avaliação da resistência de juntas coladas da madeira de Eucalyptus benthamii com diferentes adesivos e faces de colagem. Scientia Forestalis 2013; 41(99)

Iwakiri S. Painéis de madeira reconstituída. Curitiba: FUPEF; 2005.

Jankowsky IP. Colagem de madeiras. Piracicaba: Escola Superior de Agricultura "Luiz de Queiroz"; 1988. 45 p.

Klock U, Muñiz GIB, Hernandez JA, Andrade AS. Química da madeira. 3. ed. Curitiba: Universidade Federal do Paraná; 2005. 86 p. Apostila.

Kollmann FEP, Côte WA Jr. Principles of wood science and technology. New York: Springer-Verlarg; 1968.592 p. http:// dx.doi.org/10.1007/978-3-642-87928-9.

Lima CKP, Mori FA, Mendes LM, Carneiro ACO. Características anatômicas e química da madeira de clones de Eucalyptus e sua influência na colagem. Cerne 2007; 13(2): 123-129.

Loiola PL. Secagem da madeira de teca (Tectona grandis L.f) sob diferentes condições [dissertação]. Curitiba: Universidade Federal do Paraná; 2015.
MarcatiCR, Della Lucia RM. Comportamento do angicovermelho (Piptadenia peregrinabenth.) à adesão com PVA (acetato de polivinila) e resorcinol formaldeído. Revista Ceres 1996; 2(1): 7.

Marra AA. Tecnology of wood bonding: principles in practice. New York: Van Nostrand Renhold; 1992. 453 p.

Mattos RLG, Gonçalves RM, Chagas FB. Painéis de madeira no Brasil: panorama e perspectivas. BNDES Setorial 2008; 27: 121-156.

Miranda ROV, Rancatti H, Machado GO, Soares ID, Roik M. Caracterização química e potencial de utilização da madeira de Hovenia dulcis Thunb. Enciclopédia Biosfera 2013; 9: 627-635.

Motta JP, Oliveira JTS, Braz RL, Duarte APC, Alves RC. Caracterização da madeira de quatro espécies florestais. Ciência Rural 2014; 44(12): 2186-2192. http://dx.doi. org/10.1590/0103-8478cr20130479.

Plaster OB, Oliveira JTS, Gonçalves FG, Motta JP. Comportamento de adesão da madeira de um híbrido clonal de Eucalyptus urophylla $\mathrm{x}$ Eucalyptus grandis proveniente de três condições de manejo. Ciência Florestal 2012; 22(2): 323-330. http:// dx.doi.org/10.5902/198050985739.

Prata JG. Estudo da viabilidade tecnológica do uso de espécies de pinus tropicais para produção de painéis colados lateralmente (Edge Glued Panels - EGP) [tese]. Curitiba: Universidade Federal do Paraná; 2010.

Rigatto PA, Pereira JCD, Mattos PP, Schaitza EG. Características físicas, químicas e anatômicas da madeira de Hovenia dulcis. Colombo: Ministério da Cultura e do Meio Ambiente; 2001. (Comunicado Técnico; no. 66).

Sellers T Jr. Adhesive in the wood industry. In: Pizzi A, Mittal KL, editor. Handbook of adhesive technology. New York: Marcel Dekker; 1994. p. 599-614. cap. 37.

Technical Association of The Pulp and Paper Industry TAPPI. TAPPI T-264 om-07: preparation of wood for chemical analysis. Atlanta: TAPPI Press; 1997a.

Technical Association of The Pulp and Paper Industry TAPPI. TAPPI T-204 cm-97: solvent extractives of wood and pulp. Atlanta: TAPPI Press; 1997b.

Technical Association of The Pulp and Paper Industry TAPPI. TAPPI T-252 Om-12: pH and Electrical Conductivity of Hot Water Extracts of Pulp, Paper and Paperboard . Atlanta: TAPPI Press; 2002a.

Technical Association of The Pulp and Paper Industry TAPPI. TAPPI TAPPI T-222 om-15: acid: insoluble lignin in wood and pulp. Atlanta: TAPPI Press, 2002b.

Technical Association of The Pulp and Paper Industry - TAPPI. TAPPI T-211 om-12: ash in wood, pulp, paper and paperboard: combustion at $525^{\circ} \mathrm{C}$. Atlanta: TAPPI Press; 2002c.

Vivian MA, Modes KS, Beltrame R, Souza JT, Stangerlin $\mathrm{DM}$, Morais WWC et al. Influência do tratamento térmico nos defeitos de secagem da madeira de Hovenia dulcis Thunb. Ciência da Madeira 2011;2(1): 15-38. http://dx.doi. org/10.12953/2177-6830.v02n01a02. 